Original Research Paper

\title{
Separation of Powers and Institutional Autonomy at the Subnational Level in Nigeria (1999-2011)
}

\author{
Ibraheem Oladipo Muheeb and Emmanuel Remi Aiyede \\ Department of Political Science, Universty of Ibadan, Nigeria
}

\section{Article history}

Received: 08-09-2015

Revised: 08-09-2017

Accepted: 04-01-2018

Corresponding Author: Ibraheem Oladipo Muheeb Department of Political Science, Universty of Ibadan, Nigeria

Email: ibraheem_muheeb@yahoo.com

\begin{abstract}
Sub-national legislatures have remained largely underdeveloped and until recently, they have not been accorded adequate attention in Nigeria. This article highlights the performances of two sub-national assemblies 19992011. The study from which the article was derived involved a survey, supplemented with exploratory designs and content analysis. Sub-national legislatures possessed the requisite constitutional powers to function effectively but lack the complimentary capacity like experienced members, resources and facilities to guarantee independent action. The transitional Assembly 1999-2003 was largely dependent on the executive for financial and human resources and subsequent ones, 2003-2007 and 2007-2011 did not fare any better. They were unable to consolidate on their constitutionally granted powers to enhance performance due to executive intransigence; high turnover of membership and principal officers; lack of cohesion; frequent conflicts over allegiance to the executive, involving accusations and counter accusations of cultic oath-taking; and weak oversight capacity. During the period, legislative tools were merely used to achieve limited political goals. The fallouts of Resolution ' 167 ' barring the government from all financial transactions until the Assembly directed otherwise in Ogun State, were indications that House Resolutions, where and if well deployed could be a potent tool for oversight. However, a determined executive could clandestinely debar the legislature from functioning properly without necessarily dissolving the Assembly through threats and intimidation. Enduring and Democratically productive legislature-executive relation would require 'ideological and programmatic' party system, institutional independence and enhanced capacity. Sub-national Legislatures should be restructured and strengthened to enable them assert their authorities and to overcome their inadequacies.
\end{abstract}

Keywords: Nigeria, Legislature, Separation of Powers, Autonomy and Representation

\section{Introduction}

The legislature in Nigeria operates at two levels of the federation. The status of the legislature is stated in Section 4 of the 1999 constitution. Section 4(1-2) vested the legislative powers of the Nigerian Federation in the National Assembly comprising the Senate and the House of Representatives. Section 4(6-7) clearly defined the legislative powers of the States Houses of Assembly similar to those of the National Assembly (Anyaegbunam, 2000). Each state in Nigeria is a microcosm of the federal structure with separation of powers in terms of functions and personnel among the three branches of government namely the legislature, the executive and the judiciary, each of which is almost exclusively responsible for the performance of one of the functions of government. At state level, the governor, elected by popular vote, is granted extensive powers commensurate with the demand of his executive responsibilities. The constitutional provisions require that the executive recourse to the legislature for the approval of policies and for funds to execute plans and projects. These checks serve as an ultimate restraint against usurpation of the power of the legislature as well as possible arbitrary use of power by the executive. To harmonise governmental activities and achieve interinstitutional synergy, the governor is made part of the legislative process to the extent that his legislative 
proposals are the primary source of agenda for the House Assembly. Besides, his assent is required for a bill to become law going by provisions under Section 100(1-4) of the Constitution. In order to check abuse of legislative powers by a state's House of Assembly, the Constitution empowers the Governor to veto undesired legislation although the veto can be overridden by a two-thirds majority vote by the House of Assembly. This is clearly stated under Section 100(5). The principle of separation of powers and personnel as well as checks and balances are enshrined in the constitution within the context of legislature-executive relationship, which limits executive influence in and on the legislature. Section 188 of the constitution particularly empowered the State Houses of Assembly to remove-as last resort-an erring Governor or Deputy Governor as the case may be, in line with these provisions. Thus, the 1999 Constitution made adequate provisions for the effective functioning of a representative legislature.

Sub-national legislatures have however remained largely underdeveloped; and until recently, have not been accorded adequate research attention in Nigeria. While the national legislature has gained prominence in legislative studies, discussion on sub-national legislative practices has been limited. This is in spite of the fact that state legislatures as essential element of democratic government in a multi-level governance structure deserve to be studied in their own right. The character, activities and performance of the legislature and legislative processes as well as the circumstances of political exchanges at the sub-national level are crucial to the overall national governance performance. The reform initiatives geared towards entrenching transparency and accountability through federal executive initiated agencies and institutional frameworks like the Economic and Financial Crimes Commission (EFCC) and the Independent Corrupt Practices and other Related Offences Commission (ICPC), threw up fresh challenges in Nigeria's quest to institutionalize representative government and entrench separation of powers. In addition to its claim of been proactive in financial matters as regards all levels of government, anti-graft agencies particularly the EFCC allegedly used State Assemblies extensively. In a manner depicting weak dispositions to their legislative responsibilities, State assemblies were used to hound executive officials and effect leadership change of State executives in controversial circumstances on a number of occasions. The palpable failure of States' assemblies, to act swiftly and proactively on issues of financial misappropriation and other executive misdemeanours raised questions on the legislatures' power of oversight and capacity for effective checks and balances. Thus, raising concerns on the relevance of State Assemblies and their respective capacity to live up to the dictates of a worthwhile legislature-executive relation (Muheeb, 2015).
This paper highlights the Nigerian experience during the first decade of its current democratic experiment (1999-2011). The paper focuses on the performance of select subnational legislatures in representation and oversight between 1999 and 2011. The paper benefited from the report of a study that examined the performance of a sub-national legislature and the implications for representative government in Nigeria from 1999 to 2011. The study, which was a follow-up to the existing works on legislative studies in Nigeria, examined the Ogun State legislature on lawmaking, representation and oversight as a microcosm of the conflictual, distributive and transactional politics in Nigeria. The theory of institutionalisation focusing on autonomy, internal complexity and universalism provided the conceptual framework. Case study, household survey and exploratory designs were adopted. Structured questionnaire was administered to informed residents of voting age population who were able to evaluate the legislature. Indepth interviews were conducted with political, community and opinion leaders and legislators on legislature-executive relations, available resources and character of the legislature. Secondary data on constitutional powers, number and types of bills passed were drawn from the assembly, libraries and media reports. Quantitative data were analysed using descriptive statistics, while qualitative data were content analysed. The study underscores the fact that there is a limit to the extent all of the popular prescriptions in developed democracies could be applied in a straitjacket manner to the emerging democracies (Muheeb, 2015).

\section{Conceptual and Theoretical Concerns}

Discussion on the legislative-executive relations here is within the frame of federal arrangement to which Nigeria subscribes. As Cameron and Falleti (2004) observes, a federal system can either be presidential or parliamentary; to qualify as federal, a constitution must simply create executive, legislative and judicial branches of government at the subnational level. Federal systems vary in terms of which policy areas are controlled exclusively by the national government, which by the subunits and which are shared. Variation could also be a function of the overall balance of power between the national government and the sub-units and the mechanisms used to incorporate the sub-units into the decision making process. The exact nature of the division of power and institutional structures created vary between federal systems and non-federal systems and even within systems over time (Kreppel, 2005). While the executive serves as the central point of the government, the legislature serves as the suspension column of representative government both in terms of composition and operation. Separation of powers, functions and personnel inherent in a representative regime constitutionally limits executive influence on the 
legislature (Hague and Harrop, 2004). By its status and function, the legislature is a veritable platform for the harmonisation of diverse interests and for bringing government policies and programmes to the public domain thereby serving as a bridge between the government and the governed (Norton, 1990; Lijphart, 1992; Philips, 1995; Almond et al., 1996; Hans, 2000; Born and Urscheler, 2002; Hague and Harrop, 2004). It nonetheless recognises the relative independence of the judicial arm of government in all circumstances (Lijphart, 1992). The two major environments around which the assessment of the legislature revolves are: The executive and the electorate. The network of relationships between the legislature and these environments offers considerable understanding and explanation for the nature and character of the legislature (Olson, 1980).

The legislature's primary functions of representation, lawmaking and oversight provide the basis for the assessment of its performance. Oversight tools that legislatures could deploy to perform their assigned responsibilities of overseeing activities of the executive include public hearings, hearings in committees, hearings in the plenary, inquiry, parliamentary questions, visitation and interpellation (Born and Urscheler, 2002; Hague and Harrop, 2004; Olson, 2004; Remington, 2004; Pelizzo et al., 2006). However, the presence of these oversight tools is a necessary but insufficient condition for effective oversight. There are other conditions that determine the effectiveness or otherwise of the legislature. These include the specific statutory powers granted the legislature; availability of information to the legislators; the capability of committee heads; the saliency of issues and how aggressively the opposition performs its role among other historical and cultural variables. These are the bulk of factors that enable legislatures to become more or less effective in the discharge of their responsibilities and in constituency servicing over time (Brinkley, 2000; McGee, 2002; Born and Urscheler, 2002; Desposato, 2004; Pelizzo and Stapenhurst, 2004; Pelizzo et al., 2006; Barkan, 2008; Melia, 2010). Subnational legislatures in a federation are a crucial "minilaboratory" for observing and explaining how legislative institutions work in different contexts. Insights from the experiences of state legislatures may be useful to improve the legislature's overall productivity at the national level (Desposato, 2004). Richardson et al. (2004) and Desposato (2004), favour continual response to the call of Moncrief et al. (1996), that more research on representation need to be performed at the subnational level. This is particularly so in new democracies that offers a myriad of opportunities to test and develop models of representation with national appeal. The emphasis here is on critical areas of performance widely used to evaluate and analyse an institutionalised legislature, as well as areas that brought the legislature's weakpoints to the fore in representation; lawmaking; and oversight functions (Muheeb, 2014).

There are several studies on the essence, interventions and general performance of the National Assembly and the implications for the Nigeria's fledging representative government (Akinsanya and Davies, 2002; Aiyede, 2006; Eminue, 2006; Omotola, 2006; Ugoh, 2006; Obiyan, 2007). Such studies have emphasised the palpable ineffectiveness, executive dominance and resistance during the period under review. The situation has been ascribed to historical and cultural conditions like prolong authoritarian rule, the nature of the society among other socio-political and cultural dynamics (Schneier, 2004; Diamond, 1999; Theen and Wilson, 1986; Coleman, 1970). What is the experience at the subnational level? Are similar factors at play at the subnational level? To answer these questions Polsby $(1975 ; 1968)$ institutionalisation theory was adopted in explaining the circumstances of performances of the legislature in two State legislatures namely: Ekiti and Ogun States. Three dimensions of institutionalisation, namely: Autonomy (differentiation from the environment), internal complexity (intralegislature rules and modus operandi) and universalism (application of globally acceptable practices in the conduct of internal affairs) constitute the conceptual framework within this theory for assessing how the legislature has developed over time in these States (Olson, 1980; Rosenson, 2006; Richardson et al., 2004). Polsby's theory of institutionalisation argues that the legislature must not be an all-comers' institution. It entails paying attention to extant constitutional and legal powers for the legislature; resources, expertise and information available for the legislature to perform as well as the power and the political will to hold the executive accountable for its actions. Institutionalisation also requires that the legislature must be peopled by experienced individuals. While membership must record low turnover or low proportion of first-term members, leadership of the House must of necessity be reserved for the most senior serving members. Merit, precedents and internal rules, among other impersonal universally acknowledged decision criteria, must take precedence in decision-making, including assigning committee chairs. This is opposed to the peculiar and particularistic criteria of favouritism, nepotism and partisan politics.

The theory contends that, with a well-structured internal committee system, the legislature is expected to be independent of other arms of government, particularly the executive (Muheeb, 2006). The legislature must not be dependent on other arms of government but should be adequately equipped with requisite financial, human and material resources to function effectively. These authors hold the view that State executives overshadowed the legislatures on account of lack of autonomy and weak internal complexity and flagrant breaches of the 
Constitution as shall be revealed in the subsequent sections of this paper. The authors underscore the useful considerations scholars advanced in the classification of the legislature. These include an understanding of the relationship between the legislature and the electorate and between the legislature and the executive; a better understanding of the scope of parliamentary activity and legislature's policy issues; the direction of power equation, fusion of powers or separation of powers as well as the legislature's life-span, stability or non-stability of the House and so on (Coleman, 1970; Olson, 1980; Theen and Wilson, 1986; Diamond, 1999; Hague and Harrop, 2004). The rest of the paper illustrates the challenges faced by subnational legislature within Nigeria's federal architecture by examining selected major events that challenged some legislatures putting the character of these legislatures in bold relief.

\section{Legislative-Executive Relations in Nigeria}

The choice of the presidential system of government in Nigeria was against the background of the perceived shortcomings of the parliamentary system. This was as provided for by the 1979 Constitution of the Federal Republic of Nigeria. The Nigerian presidential system entails an executive presidency with separation of powers in terms of functions and personnel among the three branches of government: A legislature, an executive president and a judiciary, each of which is almost exclusively responsible for the exercise of one of the functions of government Akinsanya and Davies (2002). In pursuance of the doctrine of separation of powers, the 1979 Constitution affirms in Section 4(1-2) that the legislative powers of the Federation shall be vested in a National Assembly consisting of "a Senate and a House of Representatives". In effect, the National Assembly is exclusively vested with power "with respect to any matter in the Exclusive Legislative List set out in Part 1 of the Second Schedule to this Constitution". Similarly, the Constitution empowers a State's House of Assembly, under Section 7, to legislate on any matter not included in the Exclusive Legislative List and/or any matter "included in the Concurrent Legislative List set out in the first column of part II of the Second Schedule to this Constitution".

To harmonise governmental activities and achieve inter-institutional synergy, the President is made part of the legislative process to the extent that his legislative proposals are the primary source of agenda for the National Assembly. Besides, his assent is required for a bill to become law, i.e., an Act of the National Assembly. In order to check possible abuses of powers by the legislature, the executive, through the President, is empowered by the Constitution to overrule an unpleasant legislation through veto (Section 54 (4) of the 1979 Constitution). However, a National Assembly that is able to garner two-thirds majority votes against the presidential veto can render the assent of the President irrelevant. Similarly, in order to check abuse of legislative powers by a state's house of assembly, Section 94(4) of the Constitution empowers the Governor to veto an unpleasant legislation although the veto can be overridden by a two-thirds majority vote by the state's house of assembly (Akinsanya and Davies, 2002). In retrospect, Akinsanya recall that in several states that were virtually 'one-party' states during Nigeria's Second Republic particularly in Kano's, People's Redemption Party (PRP), Niger's National Party of Nigeria (NPN), Ogun, Unity Party of Nigeria (UPN), Ondo and Oyo's executive-initiated proposals have always been accepted and legitimized by the lawmakers without much debate and amendment. Some of the identifiable factors responsible for this are; strong party discipline particularly, in States where the Governor was also the Party Chairman; discharge of responsibilities in exchange for favours (in terms of contracts, patronage or bribes) which the lawmakers expect from the Chief Executives; and the fact that the law-makers were lackadaisical (Akinsanya and Idang, 2002).

Aiyede (2006), examines legislature-executive relations within the context of separation of powers, specifically at the national level in the face of environmental and institutional challenges. He reiterates that Nigeria has been experiencing executive dominance at the expense of the legislature, noting that constitutions vested enormous powers on the legislature to the effect that it can impeach an erring executive member on the grounds of gross misconduct, the interpretation of which rests with the legislature. The provision also forbids the judiciary from entertaining any action brought before it on impeachment. He identified party cohesion and individual aspiration of political leaders, among others, as hindrances to possible exercise of this legislative power and could also be the basis of misapplication of the power. Aiyede identifies a struggle for prestige and influence; diverse perception of powers and roles by each arm of government; opposing perception on the distribution and execution of capital projects as well as perceived efforts of the executive to weaken the legislature as possible explanation for the nature and direction of inter-institutional conflict at the national level in Nigeria since 1999. He identifies three factors which account for the intensity of legislature-executive conflict in Nigeria since 1999 as: Unequal development of the executive and the legislature; the incoherence or weakness of political parties as well as the quasicoercive or militarised strategies preferred by both the executive and the legislature. While the executive preferred blackmail, manoeuvres as against bargaining and lobbying, not a few of the legislators understand impeachment as the only potent weapon available for them to put the executive in check. 


\section{Subnational Legislative-Executive Relations}

The 1999 constitution that provided the framework for the Fourth Republic bestowed a federal arrangement on Nigeria. It is pertinent to stress that, Nigeria's thirtysix states have shared legislative history, experience in party politics, institutional structure and operational environment. This is not to discountenance slight variation in socio-cultural configuration, which is also consistently being challenged by shared experience in post-conflict state system, poverty and inequality. In addition to a bicameral legislature of two chambers at the national level there is a unicameral assembly at the State level of government. Section 4(6-7) clearly defined the legislative powers of the State Houses of Assembly similar to those of the National Assembly. Chapter V Sections 90-129 outline details on; the composition and staff of the State House of Assembly, Procedure for Summoning and Dissolution of the Assembly, Qualification for Membership and Right of Attendance, Election into the Assembly as well as Powers and Control over Public Funds including right to the conduct or investigations and to seek evidence within the confines of legislative oversight. The significance attached to the state legislature in Nigeria, derived largely from the extensive powers vested in the institution of the State Houses of Assembly at the subnational levels and the broad range of functions each is expected to perform in their respective States.

The principle of separation of powers and personnel is enshrined in the constitution with provisions limiting executive influence in and on, the legislature. These provisions include those that clearly define the direction of legislative-executive relationship vis-à-vis the principle of checks and balances. On this basis, Section $100(1-5)$ of the Constitution requires that a bill passed by the Assembly be presented to the Governor for assent and for the Assembly to by-pass the Governor's assent when and where such action is delayed or denied. Section 101 granted the Assembly power to be selfregulatory. Section 105(3) granted the Governor power to issue a proclamation for the holding of the first session of the House of Assembly or for its dissolution as and when necessary. These are similar to Sections 58 and 64 as regards the National Assembly. Section 188 empowers the State Houses of Assembly to remove-as a last resort-an erring Governor or Deputy Governor, as the case may be, in line with these provisions. This is similar to provisions under Section 143, which empowers the National Assembly to remove an erring President or Vice-President. Thus, the 1999 Constitution made adequate provisions for the effective functioning of and a representative legislature at the national and subnational levels. However, State Assemblies exhibited palpable weaknesses in holding their respective executives accountable for their respective actions, resulting in alleged federal executive-instigated summary impeachment of State Governors, arraignment and prosecution of some, indictment of many and endless investigation of others on serial allegation of official misconduct. Cases cited below better illustrate instances of State Assemblies' weak dispositions to their legislative responsibilities as well as challenges facing sub-national legislatures in the exercise of their legislative powers. Each of the State assemblies of Ogun and Ekiti States had a dose of 'executive impunity' and suffered incapacitation within the framework of federal politics to check executive excess.

\section{Ekiti State House of Assembly: Double Standard}

Peter Ayodele Fayose was the Governor of Ekiti State, Southwest Nigeria, elected under the platform of the ruling Peoples Democratic Party (PDP) in 2003. Before his ouster, he had presided over the administration of the state from May 2003 to October 2006, when the State's lawmakers impeached him on allegations of corruption, abuse of office and gross misconduct. Other allegations against the Governor included: Illegal operation of foreign accounts; illegal diversion of local government funds; receipt of illegal gifts; and illegal transfer of the sum of $\$ 100,000$ to the United States (Sayo et al., 2006). The Governor and his deputy, were served impeachment notices by twenty-four of the State's twenty-six lawmakers following allegation of gross misconduct against them by the EFCC. In controversial circumstances, two panels of investigation were set up in quick succession to determine the fate of the duo. Membership of the first panel, constituted by the State's Chief Judge was believed to be dominated by cronies of the executive (According to the Majority Leader of the State House of Assembly, "... Of the seven members appointed into the panel, two are from the Local Government of Fayose; two are his wife's relations and associates and one appointee, the closest friend of the chairman of the State Universal Basic Education Board", loyal by the governor), against the spirit of the constitution, as provided under section 188(5) (Sayo et al., 2006a). The State House of Assembly consequently disregarded the panel and instead appointed another Judge in an acting capacity. The acting Justice reconstituted the second panel with the same terms of reference. Although the governor and his deputy were cleared of all charges by the first panel; yet, when it was almost certain that the governor might not be exonerated by the second panel, he neither showed up nor made any representation at the panel sitting. However, his deputy did. The panel found the Governor guilty of all the charges and he was consequently impeached (Sayo et al., 2006b).

\section{Ogun State House of Assembly: Allegation too Weighty to be Ignored}

There was no record of legislative intervention in either of the instances of allegation of mismanagement 
of public funds levied against the Governor of Ogun State southwest Nigeria, Gbenga Daniel 2003-2011. Former President Olusegun Obasanjo and Dipo Dina, a prominent gubernatorial candidate of the leading opposition party, the Action Congress of Nigeria (ACN) made two well-circulated allegations at the time. While Dipo Dina alleged that the Governor and his wife expended 450 million Naira or $£ 1.2$ million on foreign trips, President Obasanjo had accused the Governor of mismanaging funds accruable to the state to the tune of N1 trillion or $£ 4$ billion (Daniel, 2011). The assembly was found wanting, as subsequent clarifications on the state of affairs on the allegations from Dina (Daniel dismisses this allegation as an exercise in mischief for Dipo Dina or anyone else to assert that as much as four hundred and fifty million Naira (N450 m) or about $£ 1.2$ $\mathrm{m}$ was spent by the Governor and his wife on foreign trips. To Daniel, at the time Dipo Dina Movement (DDM) made its wild allegation the state was earning an average of N1.3billion or about $\$ 2.6$ million, as monthly allocation from the Federation Accounts, out of which one billion one hundred million Naira (N1.1billion) or about $\$ 2.47$ million was being spent, on a monthly basis, on staff salaries and allowances, with nothing left to accommodate such a huge traveling allowances. Daniel was to raise a poser that the vouchers under reference, in possession of DDM, sourced in collaboration with a few state officials and published, revealed a sum less than $10 \%$ of the bogus four hundred and fifty million Naira (N450million) or about $£ 1.2$ million (Daniel, $2011 \mathrm{p}$. 302) and Obasanjo (The Governor also dismisses this allegation and his reaction runs thus: In the heat of the struggle for Ogun PDP, I was informed that former President Obasanjo had forwarded a petition to the EFCC purportedly detailing my mismanagement of the finances of Ogun State, since I became the governor (this account follows similar trend as the instances in Ekiti, Bayelsa, Plateau and Abia States identified in the introductory part of this study). ...How could my administration have mismanaged one trillion naira (N1tr), or $£ 4$ billion as alleged, when the whole revenue that accrued to the State between May, 2003 and December, 2010 did not go beyond three hundred billion, one hundred and ninety-one million, nine hundred and eighty-five thousand, six hundred and one naira, thirty kobo $(\mathrm{N} 300,191,985,601.30)$, or about $£ 1.3$ billion representing both receipts from monthly allocation from the Federation Account and internally generated revenue (Daniel, 2011 pp.497-498)) were limited to those offered by the Governor, Gbenga Daniel with no record of concrete legislative intervention (Daniel, 2011). Were it to live up to its granted powers and mandate, the state legislature could not claim to have been barred from leveraging on such allegation to further its oversight function in the interest of the public and to the benefit of the system of rule. Few instances of oversight actions were exclusive of considerable efforts committed to initiating investigation into allegation of mismanagement of public funds or corrupt practices.

\section{Discussion and Critical Appreciation}

Subnational legislatures possessed the requisite constitutional powers to function effectively but lack the complimentary capacity to guarantee independent action. The transitional Assemblies 1999-2003 were largely dependent on the executive for financial and human resources. Bills for laws to provide for the establishment of State Assemblies' Service Commissions and to make them self-accounting could not see the light of day due to executive intransigence, high rate of turnover of membership and principal officers, lack of cohesion, frequent conflicts over allegiance to the executive, involving accusations and counter accusations and weak oversight capacity. During the 2007-2011 periods, legislative tools were merely used to achieve limited political goals. The few credits due State Assemblies were overshadowed by the palpable manifestations of weakness on the part of the subnational institutions, resulting in alleged federal executive-instigated summary impeachment of state governors, express arraignment and prosecution of some, confirmed indictment of many and endless investigation of others. The Ekiti and Ogun States cases cited above better illustrate instances of State Assemblies' weak dispositions to their legislative responsibilities both in effective oversight and in representation.

State assemblies were unable to maintain their independence by managing their own affairs in unison and harmony given the disproportionate influence of the executives. This accounted for the deployment of legislative tools merely to achieve limited political goals. In the heat of legislative-executive face-off in Ogun State, the fragmented State assembly passed a resolution tagged: Resolution ' 167 ', which barred financial institutions in the country from having any financial dealings with the State government until the State legislature, directed otherwise. Fallouts of this resolution, which equally barred the State government from all financial transactions until the Assembly directed otherwise, were indications that House Resolutions, where and if well deployed could be a potent tool for oversight. However, a determined executive could clandestinely debar the legislature from functioning properly without necessarily dissolving the Assembly through threats and intimidation as witnessed in Ogun State. The executives played prominent roles in producing and removing the principal officers of State Assemblies and State Assemblies were willing tools in the hands of their respective State Executives. They were unable to check several real and perceived excesses of their Executives on critical issues of mismanagement and misappropriation of public funds despite the socioeconomic implications on the people. Some State Assemblies were not only viewed as accomplices but 
were rightly accused of subverting the basic tenets of representative government through unhealthy compromises. A good number of the noticeable gridlock in the inter-institutional relations as experienced in Ogun State and appropriation of legislative powers by executive agencies as witnessed in Ekiti State resulted from such compromises. The continued prevalence of corruption and the inability to stem the tide of financial mismanagement by the public office holders were major indicators of the failure of the State Assemblies in their oversight functions. This coupled with the poor monitoring of budget implementation led to executive recklessness in the submission and implementation of annual budgets, thus making the exercise a mere ritual. A number of issues and factors account for these institutional weakness particularly as regards effective oversight and representation (Muheeb, 2016a; 2016b; 2016c; 2016d).

\section{Understanding Why}

Fundamentals of Autonomy: Given that institutional autonomy is at the heart of legislature-executive relations within the context of separation of powers, none of these assemblies was independent of the Executive. The assemblies were unable to statutorily hold successive executive accountable. Although, the constitution vested the power of scrutiny and approval of the budget on the legislature; yet the legislature itself depended on the executive for financial survival. The assemblies were at the mercy of the executive through the state Commissioner of Finance, the Commissioner for Budget and the Accountant-General of the State. Expectedly, the executive did withheld funds meant for the legislature, when the executive felt uncomfortable with developments that-in its estimation-appeared to challenge the operation of the executive. In the ensuing process, the legislature was unable to prevent legislators' personal financial interests from unduly influencing their official action in relation to the executive.

Internal Complexity: As noted earlier, each of the State assemblies under reference recorded high turnover of leadership and membership. Most members of the 1999-2007, 2003-2007 as well as the 2007-2011 assemblies were either nominated or selected and their election bankrolled by 'godfathers', including traditional rulers, influential party and opinion leaders. This accounted for the attendant indiscipline, disregard for due process, party fractionalisation, conflicts over allegiance to the governor, involving accusations and counter accusations of graft and cultic oath-taking and disregard for rules of legislative-executive engagement. The visible executive interference, lack of expertise and facilities and institutional cohesion adversely affected the legislature's disposition towards the executive. This deficit hampered the assemblies' effectiveness by making them subservient to the executive at best. The assemblies were not institutionalized on account of quality of members, membership and leadership composition, observance of house rules, enforcement of discipline and inadequate capacity to initiate independent action.

Missing Essential Cohesion: Polarised and incapacitated in spite of the single-party majority prevalent among the legsilatures, unity of prupose was elusive in most of the assemblies. The sixth assembly in Ogun State and the fifth in Plateau and Ekiti States were fraught with frictions, antagonism, factionalisation and unhealthy compromises which jeopardised mutual respect and cordiality. Cohesion was also made difficult by members' diverse interests, preferences and direction of loyalty, a development that was exploited by the respective executives to their advantage at the expense of meaningful legislature-executive engagement. This adversely affected the view the general public held of the legislature.

The Majority Curse: Explanations abound in the literature on the nexus between party politics and legislative efficiency. Hague and Harrop (2004) specifically observe that in party-dominated legislatures, the legislative function is reduced to quality control of executive action. This was the case under the Peoples Democratic Party (PDP) dominated assemblies of 19992003, 2003-2007 and 2007-2011 respectively in Bayelsa, Ekiti and Plateau States. On each of these instances, a good number of bills that became laws passed through the assembly without being initiated or modified by it. Thus, the legislature played less significant roles in legislation. The initiative in framing bills rested squarely with the executive and the party and often the legislature, was 'reactive' to executive initiatives (Coleman (1970); Desposato (2004); Hague and Harrop (2004); Oslon, (1980); Theen and Wilson, 1986). Conversley, these Assemblies as well as the Alliance for Democracy dominated 1999-2003, the PDP domianted 2003-2007 and the 2007-2011 Assemblies in Ogun State enjoyed considerable party hegemony. Inspite of these hegemony, the PDP dominated 2003-2007 Assembly in Ekiti, the 2007-2011 Assembly in Plateau and the 20072011 Assembly in Ogun State suffered fractionalisation, international wranglings and conflicts.

Formidable Opposition Gap: In retrospect, with a near absolute majority, except on politics and electionrelated issues, there was no record of concrete challenge for any of the 1999-2003, 2003-2007 and 2007-2011 State assemblies by the major opposition parties at the time. A major manifestation of this structural anomaly was the appropriation and personalisation of the ruling parties' machinery by the Governors as leaders of their respective parties across the States. This was given fillip by the perceived excessive use of coercion, intimidation and harassment by some of the Governors to bring uncooperative legislators to reckoning. The situation was not helped by the dearth of virile opposition that could have posed a formidable challenge to the ruling parties and proffer credible alternative policy options (Muheeb, 2016a; 2016b; 2016c; 2016d). 


\section{Concluding Remarks}

Regardless of their shortcomings, State Assemblies contributed to democratic consolidation when viewed against empowered executives through prolonged authoritarian rule. As democratic institutions, assemblies provided the desirable alternative to authoritarian rule, prevented the absolute reign of dictatorship and justified representative government. In their composition in geographical terms, the assemblies represented the people. They symbolised legitimacy and popular support for the system of rule and provided platform for exchange of views and harmonisation of interests between and among groups and individuals. They screened the executive's nominees for appointments and postings. They received, occasionally made selective adjustments and passed annual budgets and supplementary appropriation bills. They also recorded considerable success in law making. They were major subnational stabilisers in Nigeria's fragile and fledgling democracy. They occasionally played prominent roles in shaping the business environment, calling into question several managers of government business and intervened in critical transactions involving government and private concerns, including multinationals and corporate entities. These and few other credits that could have accrued to the state assemblies were erroded by the several manifestations of weakness on the part of the legislatures, resulting in a number of national executive-instigated summary impeachment of State Governors, express arraignments and prosecutions of some, confirmed indictments of many and endless investigations of others. Perhaps, subnational legislatures were just developing the right disposition, strategies and structures that could enhance legislative efficiency and effectiveness. Some of the issues identified in this study as accountable for the noticeable lapses aligned with those advanced identified in the literature, to the effect that the executives were reluctant to grant rights of scrutiny, in apparent display of protectionist and authoritarian tendencies.

This paper argued that subnational legislatures were not autonomous from the executive during the first decade of the Nigeria's Fourth Republic. The legislatures suffered from poor capacity as well as the legitimacy deficit that ensued from the pre-election nomination and selection process of assembly members' across the states of the federation. Basic legislative rules were established during the various legislative terms but were observed in breach. Attempts by the national government through executive instruments to breath life into state assemblies' internal rules and constitutional powers resulted in fractionalisation of not a few State assemblies and endless frictions with the executives. This culminated in intra-institutional and inter-institutional crises that grounded a number of States in governance and administration terms. The turn ver of leadership of the legislatures was not only rampant; the turnover of membership was equally quite high, starving many assemblies of the benefit of experience. Subnational legislatures were subservient in their dealings with the executive and generally weak in furthering their representative calling. Enduring representative government through institutionalized Legislatures and productive legislative-executive relations would require 'ideological and programmatic' party system, institutional independence, enhanced capacity and sustained civic spirit. Sub-national Legislatures should be restructured and strengthened to enable them assert their authorities and to overcome their collective inadequacies.

\section{Acknowledgement}

Profound gratitude to Professor Kunle Ajayi, University of Ado-Ekiti; Professor Muyiwa Falaiye, University of Lagos, Akoka; Professor S.A Tella, Olabisi Onabanjo University, Ago-Iwoye; Dr. Emeka Okafor and Dr. Adetayo Idowu Johnson, both of the University of Ibadan, Ibadan Nigeria; Dr. Adelaja Odukoya, Dr. Ayo Yusuff, Dr. Akeem Akinwale and Akin Onipede of the University of Lagos, Akoka Nigeria for their helpful interventions in and invaluable contributions to the course of the research work from which this paper benefited. Huge debt of gratitude to Ibijoke LadeleAdeboyejo (Mrs.) for her editorial assistance, Diyal Manji Augustine, Samuel Akingbade and Veronica Udoka, all of the Centre for Black and African Arts and Civilization (CBAAC), Lagos for their secretariat and logistics suppoort.

\section{Funding Information}

The doctoral research on which this paper derived was a self-sponsored undertaking. Authors of this paper/extract neither receive any sponsorship support nor grant from any individual or institution.

\section{Authors' Contributions}

Ibraheem O. Muheeb: Conducted the research and authored the thesis from which this extract derived under the supervision of Emmanuel Remi Aiyede.

Emmanuel Remi Aiyede: Contributed in providing the bulk of the literature as well as in developing relevant concepts and research designs. He also read and approved the final manuscript of this publication.

\section{Ethics}

This article is original and contains unpublished material. The corresponding author confirms that all of the other authors have read and approved the manuscript and no ethical issues involved. 


\section{References}

Aiyede, R.E., 2006. Legislature-Executive Relations in Nigeria's Democracy. In: Challenges of Sustainable Democracy in Nigeria, Ojo, E.O. (Ed.), J. Archers, Ibadan.

Akinsanya, A.A. and G.I.J. Idang, 2002. Nigerian Government and Politics 1979-1983. 1st Edn., Wusen Publishers, Calabar, ISBN-10: 9780511563 , pp: 448.

Almond, G.A., B.G.J. Powell and R.J. Mundt, 1996. Comparative Politics: A Theoretical Framework. 4th Edn., Longman, New York, ISBN-10: 0321089855 , pp: 209.

Anyaegbunam, E.O., 2000. Assembly Handbook: "A Legislators' [sic] Companion". 1st Edn., Friedrich Ebert Foundation, Lagos, ISBN-10: 9783430696 , pp: 156.

Barkan, J.D., 2008. Legislatures on the Rise? J. Democracy, 19: 124-137.

Born, H. and M. Urscheler, 2002. Democratic accountability and parliamentary oversight of multinational peace support operations: Proceedings of the 4th Workshop on Strengthening Parliamentary Oversight of International Military Co-Operation and Institutions, Jul. 12-14, Brussels, Forces, pp: 8-13.

Brinkley, A., 2000. The Unfinished Nation: A Concise History of the American People. 3rd Edn., McGrawHill, New York, ISBN-10: 0072295600, pp: 568.

Cameron, M.A. and T.G. Falleti, 2004. Federalism and the separation of powers at the subnational level. Proceedings of the Annual Meeting of the American Political Science Association, Sept. 2-5.

Coleman, J.S., 1970. The Politics of Sub-Saharan Africa. In: The Politics of the Developing Areas, Gabriel, A.A. and J.S. Coleman (Eds.), Princeton University Press, Princeton, pp: 354-360.

Daniel, G., 2011. Daniel in lion's den: Memoirs of Otunba Gbenga Daniel. 1st Edn., Frontline Books, Ibadan.

Desposato, S.W., 2004. Explaining Patterns of Oversight in Brazilian Subnational Governments. In: Legislatures and Oversight, Pelizzo, R. and R. Stapenhurst, (Eds.), pp: 58-58.

Diamond, 1999. Comparative Government and Politics: An Introduction. 1st Edn., Palgrave Macmillan, New York, pp: 98.

Eminue, O., 2006. Executive-Legislature Relations: Some Preliminary Observations on the Budgetry Process. In: Challenges of Sustainable Democracy in Nigeria, Ojo, E.O. (Ed.), Ibadan, J. Archers, Ibadan.

Hague, R. and M. Harrop, 2004. Comparative Government and Politics: An Introduction. 6th Edn., Macmillan, Basingstoke, ISBN-10: 0333693353, pp: 355.

Hans, K., 2000. Comparative Democratic Politics - A Guide to Contemporary Theory and Research. 1st Edn., SAGE Publications, London.
Kreppel, A., 2005. Understanding the European parliament from a federalist perspective: The legislatures of the USA and EU compared. Proceedings of the European Union Studies Association Conference, (SAC' 05), Austin Texas.

Lijphart, A., 1992. Parliamentary Versus Presidential Government. 1st Edn., Oxford University Press, New York.

McGee, D.G., 2002. The Overseers: Public Accounts Committees and Public Spending. In: Parliamentary Oversight for Government Accountability, Pelizzo, R., R. Stapenhurst and D. Olson (Edn.), The World Bank.

Melia, T.O., 2010. What makes legislatures strong? J. Democracy, 21: 166-170

Moncrief, G., J.A. Thompson and W. Cassie, 1996. Legislative representation in a single-member versus multiple-member district system: The Arizona State Legislature. Political Res. Q., 57: 337-337. DOI: $10.1177 / 106591290405700214$

Muheeb, I.O., 2006. A case for vibrant and sustainable internal committee system in democratic federal Nigeria. Nigerian Forum, 27: 347-347.

Muheeb, I.O., 2015. The legislature and representative government in OGUN state Nigeria, 1999-2011. $\mathrm{PhD}$ Thesis, University of Ibadan.

Muheeb, I.O., 2016a. Characterizing Nigeria's Fourth Republic Legislature (1999 - 2015), Occasional Paper series, No. 78. The Centre for Advanced Studies of African Society (CASAS), Cape Town (University of South Africa) South Africa.

Muheeb, I.O., 2016b. The Legislature and Party Politics in Nigeria's Fourth Republic. 1st Edn., Concept Publications Limited, Lagos.

Muheeb, I.O., 2016c. The Nigerian legislature and the political economy of obasanjo presidency. African J. Politics Society, 2: 5-35.

Muheeb, I.O., 2016d. Frequency, substance and procedural shortcomings of state level impeachment campaigns in an emerging federal democracy. J. Social Sci., 12: 117-128. DOI: 10.3844/jssp.2016

Norton, P., 1990. Legislatures. 1st Edn., Oxford University Press, Oxford ISBN-10: 019827582X, pp: 336.

Obiyan, S.A., 2007. An Evaluation of the Role of the Legislature as an Institutional Actor in Nigeria's Democratic Process in the Fourth Republic (19992006). In: Nigeria Beyond 2007: Issues, Challenges and Prospects, Anifowose, R. and T. Babawale, (Eds.), Concept Publications, Lagos, Nigeria, ISBN-10: 9788065953.

Olson, D.M., 1980. The Legislative Process: A Comparative Approach. 1st Edn., Harper and Row, New York, ISBN-10: 0060449195, pp: 483. 
Olson, D.M., 2004. Administrative Review and Oversight: The Experiences of Post-Communist Legislatures. In: Legislatures and Oversight, Pelizzo, R. and R. Stapenhurst, (Eds.), pp: 58-58.

Omotola, S.J., 2006. Impeachment Threats and Nigeria's Democracy. In: Challenges of Sustainable Democracy in Nigeria, Ojo, E.O. (Ed.), Ibadan, J. Archers, Ibadan.

Pelizzo, R. and R. Stapenhurst, 2004. Legislatures and oversight. Food Agriculture Organization United Nations.

Pelizzo, R., S. Rick and D. Olson, 2006. Parliamentary oversight for government accountability. Loyola University Chicago.

Philips, 1995. Philips semiconductors concise catalogue. Philips semiconductors.

Polsby, N., 1975. Classical Analysis of Parliament in "Legislatures." In: Governmental Institutions and Processes, Greenstein, F.I. (Ed.), Addison-Wesley Pub. Co., Reading,

Polsby, N., 1968. Cited in Peverill Squire 1992. "Theory of Legislative Institutionalisation and the California Assembly", http://links.jstor.org/sici?

Remington, T.F., 2004. Separation of Powers and Legislative Oversight in Russia. In: Legislatures and Oversight, Pelizzo, R. and R. Stapenhurst. pp: 58-58.

Richardson, J. L.E., B.E. Russell and C.A. Cooper, 2004. Legislative representation in a single-member versus multiple-member district system: The Arizona state legislature. Political Res. Q., 57: 337-344.

DOI: $10.1177 / 106591290405700214$
Rosenson, B.A., 2006. The impact of ethics laws on legislative recruitment and the occupational composition of state legislatures. Political Res. Quarterly, 59: 619-619. DOI: $10.1177 / 106591290605900411$.

Sayo, I., A. Yinka and O. Mustapha, 2006a. Ekiti assembly removes fayose, deputy. The Guardian. Lagos. Sayo, I., Ekiti house suspends chief judge: Freezes state accounts. The Guardian, Lagos.

Sayo, I., M. Ogunsakin and J.A. Ogbodo, 2006b. Speaker protests as ekiti CJ names panel on fayose. The Guardian. Lagos.

Schneier, E., 2004. Emerging Patterns of Legislative Oversight in Indonesia. In: Legislatures and Oversight. Pelizzo, R. and R. Stapenhurst. pp: 58-58.

Theen, H.W.R. and I.F., Wilson, 1986. Comparative Politics: An Introduction to Six Countries. 4th Edn., Prentice Hall, London ISBN-10: 0130835730, pp: 549.

Ugoh, S., 2006. Reflections on the Legislature's Role in Nigeria's Democracy. In: An Agenda for a New Nigeria: The Imperative of Transformation, Anifowose, R. and T. Babawale (Eds.), Concept Publications, Lagos, ISBN-10: 9788065775, pp: 452. 